\title{
Water Management and Crop Resistant Varieties Adaptation Due to Climate Change By Farmers
}

\section{Adeleke Taofik TOWOLAWI ( $\nabla$ taofiktowolawi@yahoo.com )}

Federal University of Agriculture Abeokuta College of Environmental Resources Management https://orcid.org/0000-0003-4242-4402

\section{Olusegun Oguntoke}

Federal University of Agriculture Abeokuta

\section{Babatunde S. Bada}

Federal University of Agriculture Abeokuta

Joseph 0. Adejuwon

Federal University of Agriculture Abeokuta

\section{Research Article}

Keywords: Multiple Regression Analysis, Rain-fed Agricultural, CEADESE, Nigeria, World Bank

Posted Date: July 20th, 2021

DOl: https://doi.org/10.21203/rs.3.rs-711465/v1

License: (c) (1) This work is licensed under a Creative Commons Attribution 4.0 International License. Read Full License 


\title{
Water management and crop resistant varieties adaptation due to climate change by farmers
}

\author{
Adeleke T. Towolawi ${ }^{1,2 *}$, Olusegun Oguntoke ${ }^{2}$, Babatunde S. Bada ${ }^{2}$ Joseph O. Adejuwon $^{3}$ \\ ${ }^{1}$ Center for Excellence in Agricultural Development and Sustainable Environment (CEADESE), Federal University \\ of Agriculture, Abeokuta, PMB 2240, Ogun State, Nigeria; ${ }^{2}$ Department of Environmental Management and \\ Toxicology, Federal University of Agriculture, Abeokuta, PMB 2240, Ogun State, Nigeria; ${ }^{3}$ Department of Water \\ Resources Management and Agrometeorology, Federal University of Agriculture, Abeokuta, PMB 2240, Ogun \\ State, Nigeria.
}

*Corresponding author: (Adeleke T. Towolawi) taofiktowolawi@yahoo.com, orcid/org: 0000-0003-4242-4402, +2348060172946 .

\begin{abstract}
The threats of climate change on agricultural systems, water availability and crop performance put pressure on food security and zero hunger. The effects call for multifaceted mitigation and necessitate this research to investigate water management (W.M.) and crop varieties (CRV) adaptation being used by the rain-fed farmers that have the records of yearly high agricultural produce. The research distributed 1600 copies of pretested questionnaire across four (Benue, Edo, Niger and Ondo) states in Nigeria through the national Agricultural Development Programmes offices. The retrieved copies were coded in Excel spreadsheet, descriptively analysed in SPSS v23 and subjected to multiple regression analysis. The results indicated that three W.M. (riverside cultivation, irrigation practising and mulching) entered the Benue model but each for Ondo, Edo and Niger, respectively. All the CRV (SDT: selecting different technology, HYV: high yielding varieties, WRV: water-resistant varieties, DRV: drought-resistant varieties except DiRV: disease-resistant varieties) entered the Benue model, but DRV for Edo, WRV and DRV for Niger while DiRV for Ondo. General data of each state was significant $(\mathrm{p}<0.05)$. Benin and Niger States had the highest variance $(12.5$ $\%$ W.M. and $21.7 \%$ CRV). Durbin-Watson value $<2$ indicated positive autocorrelation. Mulching worked best for farmers across the states while WRV and DRV were not in Ondo and Edo. Choice of W.M. and CRV differed across the study states and the research would suggest different climate change adaptation for farmers on both water management and crop varieties.
\end{abstract}

Keywords: Multiple Regression Analysis; Rain-fed Agricultural; CEADESE; Nigeria; World Bank 


\section{Introduction}

The impact of climate change is inevitably not limited to disease, water and drought from pest invasion, rainfall pattern fluctuation, and dry spells, respectively, that crops ought to cope with from appropriate technological selection and high yields. The climate change effect is widespread and felt through direct impacts on water resources. The results include fluctuations/ changes in rainfall pattern, unsafe events with droughts and water quality declines (Bates et al. 2008), imperfect agricultural produce, crop yields per hectare, and poor annual turn out of crops. Shortage in farmland water supply (MEA 2005) and crop yield is inevitable, resulting in the demand for water to meet agricultural demand (CAoWMiA 2007) and dramatically increasing crop varieties. Climate change effects keep rising. All the spheres of the environment experienced the impacts of climate change as agricultural farmland struggles with the shortage of water supply (Chebil et al. 2019), and the resistant crop varieties perform well. Unlike food demand, the availability of water is not throughout the year to pressure the farmers to explore various ways to continue and meet the population food demand.

Crop farmers are adapting to the threat of climate change (Elias et al. 2019). The situations make coping with climate change a significant concern and threat to crop farmers across the agricultural regions (Räsänen et al. 2016). The farmer's water management and crop varieties performance to cope with climate change vary with time across the areas (Raza et al. 2019). The United Nations included water management in its sustainable development goals for geographic and sectoral scope in dealing with climate change dry-spells (Dovers and Hezri 2010). DWA (2013) viewed that strategic and effective water use is essential in water-stressed countries. The farmers, in turn, explore natural water sources (such as a river), the potential of green water source (which is mulching) and resistant crop varieties for adaptation to the threats of climate change. Some practice irrigation and riverside cultivation. Others

engage in changing irrigation scheduling to supply timely and accurate water to the growing crops, thereby growing crops along river banks, irrigating the crop fields and nursery beds and opting for crop-resistant varieties (Chimwanza et al. 2005).

Instead of direct water supply, covering the soil with dead or harvested plant debris as a green water strategy or mulching is explored and found helpful (Lok 2015). Mucina et al. (2006) viewed mulching for soil water retention to regularise evaporation, exceeding soil moisture supply in the tropical environment. The study of Campiglia et al. (2010) used mulch in crop farming as an effective cropping method to save water and moderate soil temperature 
(Zegada-Lizarazu and Berliner 2011). The authors confirmed that mulch treatment achieved optimum utilization of soil water and seedling development. Cook et al. (2006) observed that mulch improved soil water content and plant water uptake. The study of Kumar and Dey (2011) observed that mulch increased diffusion of water under vapour pressure gradient in the growing season, showing that water availability would be higher under mulched than unmulched soil. How the farmers respond to water management and crop varieties improvement from the threats of climate change is necessary for decision making, and proper implementation of the existed and newly carved strategies in agricultural sectors to ensure that food supply meets the demand of and secure the food availability (Arbuckle et al. 2015). The current research compared water management and seed resistant varieties adapted across four selected rain-fed areas by the farmers to cope with climate change and improve their decisions.

\section{Materials And Methods}

\subsection{The Study Areas}

The four chosen states are known for their agricultural produce across the nation, which can be affected by the dry spells of climate change through rainfall pattern distribution. The states are in the derived guinea savanna and typically practising rain-fed agriculture. Benue state in the eastern hemisphere, Edo and Ondo states are in the southern hemisphere, while Niger state is in the western hemisphere. Coordinates of the Benue is $7^{\circ} 19^{\prime} 59.99^{\prime \prime} \mathrm{N}$ and $8^{\circ} 45^{\prime} 0.00^{\prime \prime}$ E, Edo is $7^{\circ} 19^{\prime} 59.99^{\prime \prime} \mathrm{N}$ and $8^{\circ} 45^{\prime} 0.00^{\prime \prime} \mathrm{E}$, Ondo is $7^{\circ} 10^{\prime} 0.01 " \mathrm{~N}$ and $5^{\circ} 04^{\prime} 59.99^{\prime \prime} \mathrm{E}$, and Niger is $10^{\circ} 00^{\prime} 0.00^{\prime \prime} \mathrm{N}$ and $6^{\circ} 00^{\prime} 0.00^{\prime \prime} \mathrm{E}$.

\subsection{Data Gathering}

The questionnaire administration followed a multi-stage sampling procedure (Amujoyegbe 2010), considering rainfed agricultural areas with a high quantity of yearly produce (Stage 1) and selecting the farmers according to the Agricultural Development Programme (ADP) structure (Stage 2) which varies across the states in Nigeria, though with the same mode of operation. Edo state's ADP has three zones: North, Central and South. Benue has three: North, Central and East. Ondo state has four: Ikare, Okitipupa, Ondo and Owo. Niger state has three: Zone A (Niger-South), Zone B (Niger-Central), Zone C (Niger-East). Farmers were reached through the ADP extension offices. The multiple options on the questionnaire were "Yes, No, Undecided and Not understood," considering the dynamic natures of 
human and educational background (VARK Model 2020). The water management (W.M.: practising irrigation, changing irrigation schedule, riverside cultivation and mulching) and crop resistant varieties (CRV: selecting technology, high yield, water, drought and disease) adaptation strategies were meticulously selected from previously published articles. The sample size (n) chosen from the population of farmers $(\mathrm{N})$ under the scheduled meetings of ADP across the farmers in each state was determined using the Cochran (1963) Formula

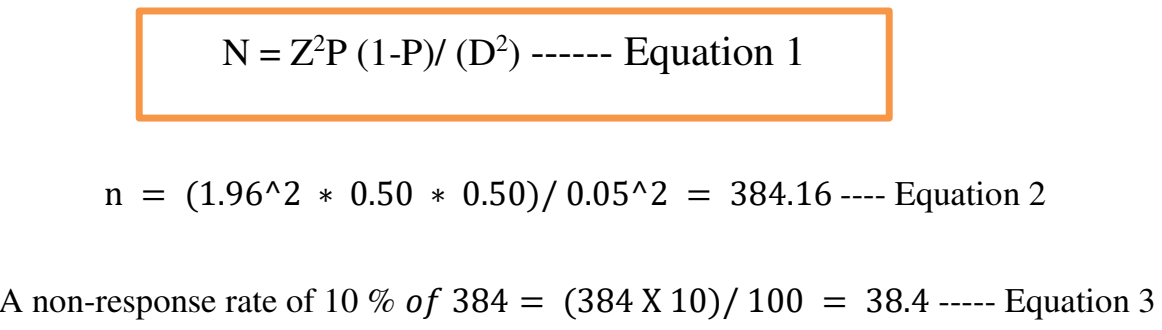

where $\mathrm{n}=$ minimum sample size required,$\quad \mathrm{z}=$ confidence limit of the survey at $95 \%(1.96)$, $\mathrm{p}=$ proportion of respondents/ farmers, $\mathrm{d}=$ absolute deviation from true value (degree of accuracy) $=5 \%$. Obtained values from equations 2 and 3 were rounded off; 420 copies of the questionnaire were administered. The questionnaire was pretested with $10 \%$ among final year students of Agriculture in FUNAAB for validation using Cronbach's Alpha (0.75), thereby allowing proper scrutiny and rephrasing some of the items under each questionnaire theme before administration across the four states.

\subsection{Statistical Analysis}

The farmers' responses were coded in Microsoft EXCEL-2010, transferred to Pivot Table and descriptively analyzed for frequency (converted to bar chart) and percentage (entered manually on each bar chart). Mean of the farmers' biodata (gender, age and education) was regressed on the mean of each W.M. and CRV strategy using regression analysis (RA) with SPSS version 22. Specific W.M. and CRV chosen in each state was ascertained through stepwise method of RA. 


\section{Results and discussion}

\subsection{Descriptive analysis of the strategies to water management adaptation}

The responses: 62, 60, and $60 \%$ in Benue, Niger and Ondo state respectively showed that the farmers did not practise irrigation-fed agriculture while $62 \%$ did in Edo state (Fig. 1). The indication then was that $75 \%$ of the study states relied on rain-fed agriculture, which would highly be affected by the rainfall fluctuation that the climate change might bring about. Reduction in rainfall pattern distributions across these 3 out of the 4 areas will affect crop farming activities from the planting inception to the harvesting period. The respondents showed that the influences of adequate irrigation revolve around the growth processes that span from seedbed preparation, germination, root growth, nutrient utilization, plant growth and regrowth, to the yield and quality of the produce in entirety. Irrigation is a sustainable way to moderate when and how water is available to the crop fields and intensify farming systems (Bekele and Drake 2003). It enhances crop performance and yield in the regions that rely on rain-fed farming (Barrett and Swallow 2006), is an approach that transforms and reorients agricultural development under the new realities of climate change (Lipper et al. 2014), and a strategy to improve water management (You et al. 2014). Choice of irrigation systems depends on the knowledge of equipment and system design and species of the Crop, growth phase, root structure, soil composition, and land formation. Plant water usage efficiency is a foremost thing worthy of attention to grasp the quantity of crop water requirements at various growth stages and prevailing climatic conditions (VSG 2018). Adopting irrigation-fed farming even at a small scale is previewed as a climate-smart agriculture practice now that dry spells and the occurrence of drought increase from the effects attributable to climate variability and change (Long et al. 2017).

Planning a timely and accurate water supply arrangement to crops was observed to be lagging across Niger, Benue, Edo and Ondo with 78, 60, 58 and $48 \%$, respectively (Fig. 2). The high \% of "No" response indicated that the farmers hardly considered irrigation schedule in farming systems and agricultural practices. The farmers might not see irrigation scheduling practice as a primary tool to improve water-consuming efficiency, enrich availability of water resources, enhance soil quality and boost crop yields (Khalil et al. 2006). The respondents might hardly see the necessity for crop water productivity linked to irrigation scheduling, which FAO (2003) emphasized as a useful indicator. Change in yield from the threats of climate change is possible in regions where there is no proper irrigation scheduling (Torriani et al. 2007). Low turnout of maize and wheat crops was observed by Diaz-Ambronna et al. (2004) as the implications of climate change fluctuations. 

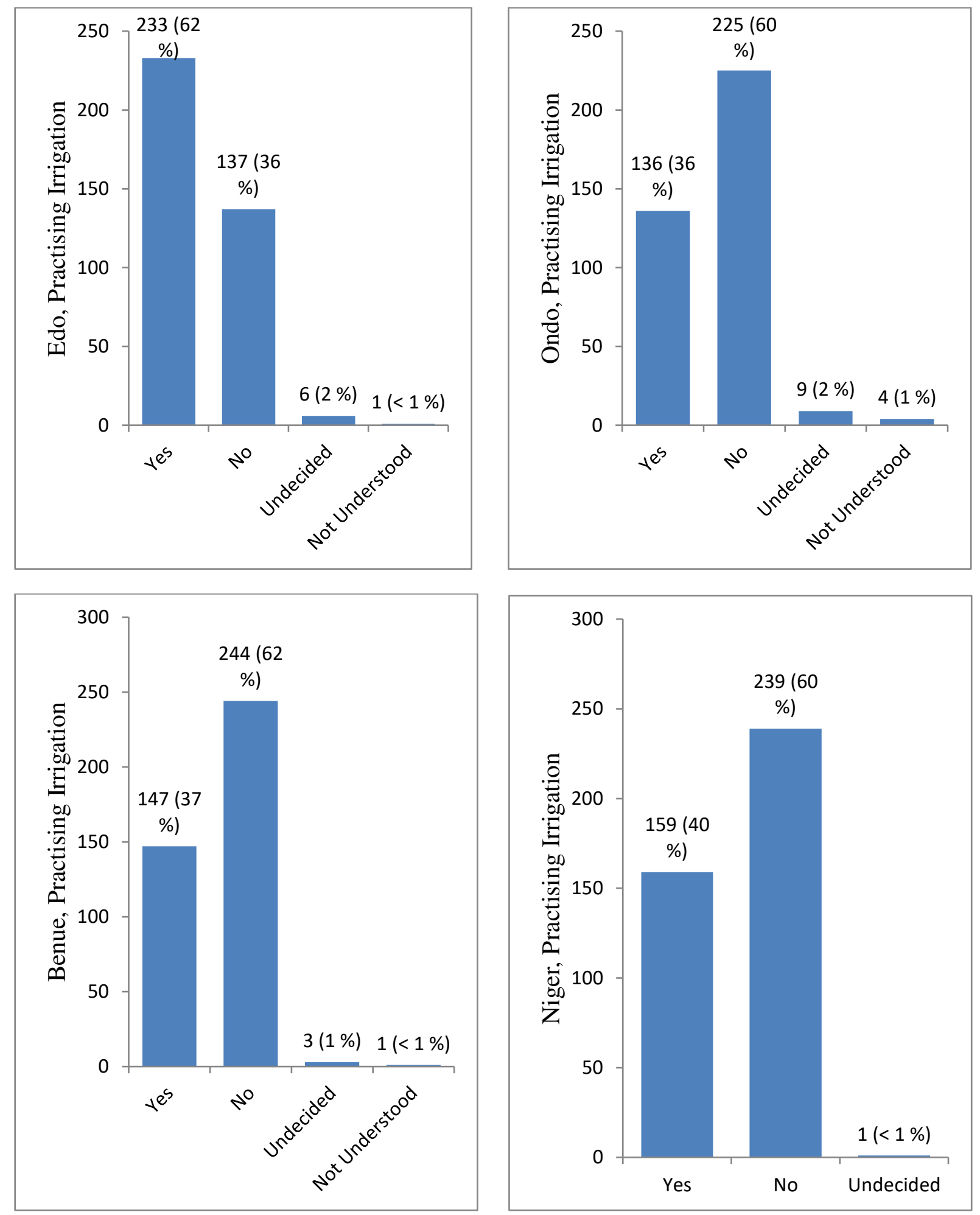

Fig. 1 Practising irrigation across the four study states 
The study of El Afandi et al. (2010) reported that changing irrigation schedule was an active adaptation choice for crop yield improvement. Gu et al. (2017) had that water stress-based irrigation scheme could be watereconomical and sustain high crop yield in less water available region but requires more water to increase crop yield in water enriched area. Consideration for functional and proper irrigation scheduling and the most efficient utilization of water and optimal production needs a desire for frequent determination of the soil water conditions across the root zone of the crop being grown (Wrigley 2006). Thus, the overview illuminated why respondents across the four study states were skeletally embracing the practice of irrigation scheduling, which draws attention to meticulous timing and accuracy.

The further inquisition was to know if there were riverside cultivations to assist in water management strategy in the era of current and looming climate change effects on farming practices. The \% of respondents: 75, 68, 67 and 46 across Edo, Benue, Niger, and Ondo states indicated there was hardly riverside cultivation practice (Fig. 3). It could imply that farmers would strive extra efforts to convey water for crop watering from their homes. The exercise routine could be tiring from the keenness to ascertain adequate water supply for better-growing performance or subject the planting activities to severe drought from the climate change. The possibility of river overflow might discourage farmers instead of seeing the advantage of closeness to the water sources.

Zidana et al. (2007) study on riverbank cultivation said the practice might face yield loss from the pronounced environmental degradation. NIWA (2016) justified that the experienced disaster mostly from river overflow is triggered by non-technical agricultural practice. However, the Queensland Government (2006) reiterated that riverside cultivation is immemorial and viewed with mixed feelings. Dzvurumi (2008) also supported that river banks are endowed naturally on the locally impoverished community small scale farmers to exploit with great relief to cultivate. Riverside cultivation ought to have been a choice influenced by local land pressures, enriched soils with highly more extended moisture contents, promising agricultural productivity and drought mitigating measure, and nearness to the regular water source (Hardlife et al. 2017). The advantages of riverside cultivation are not limited to mineral-rich silt and soil organic matter from the soil deposits when the river recedes (Hugget et al. 2004; Zidana et al. 2007). Urban suburb or small-scale farmers are fond of cultivating near riverbank because land acquisition is not cost-effective (The Chronicle 2011). 

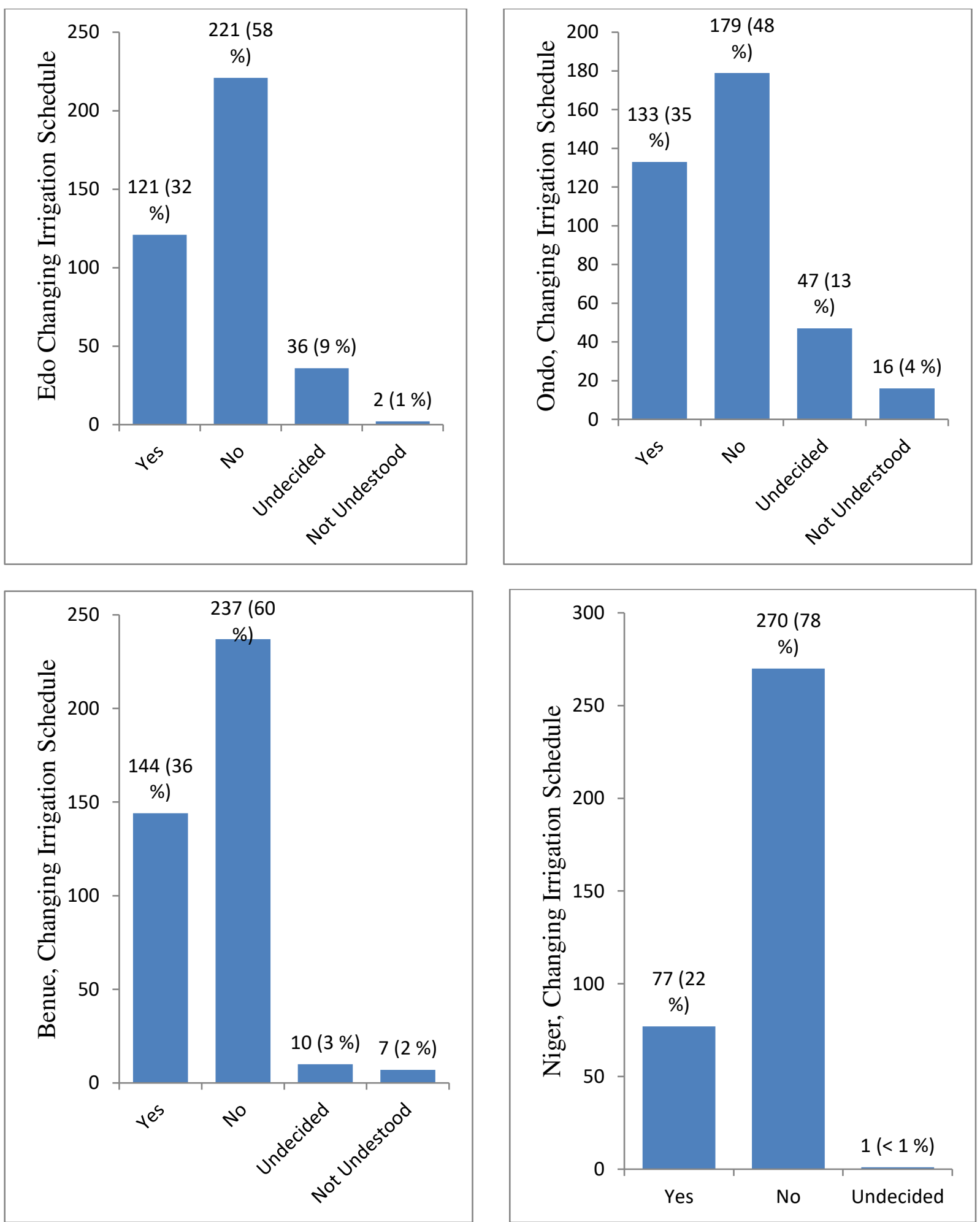

Fig. 2 Changing irrigation schedule across the four study states 

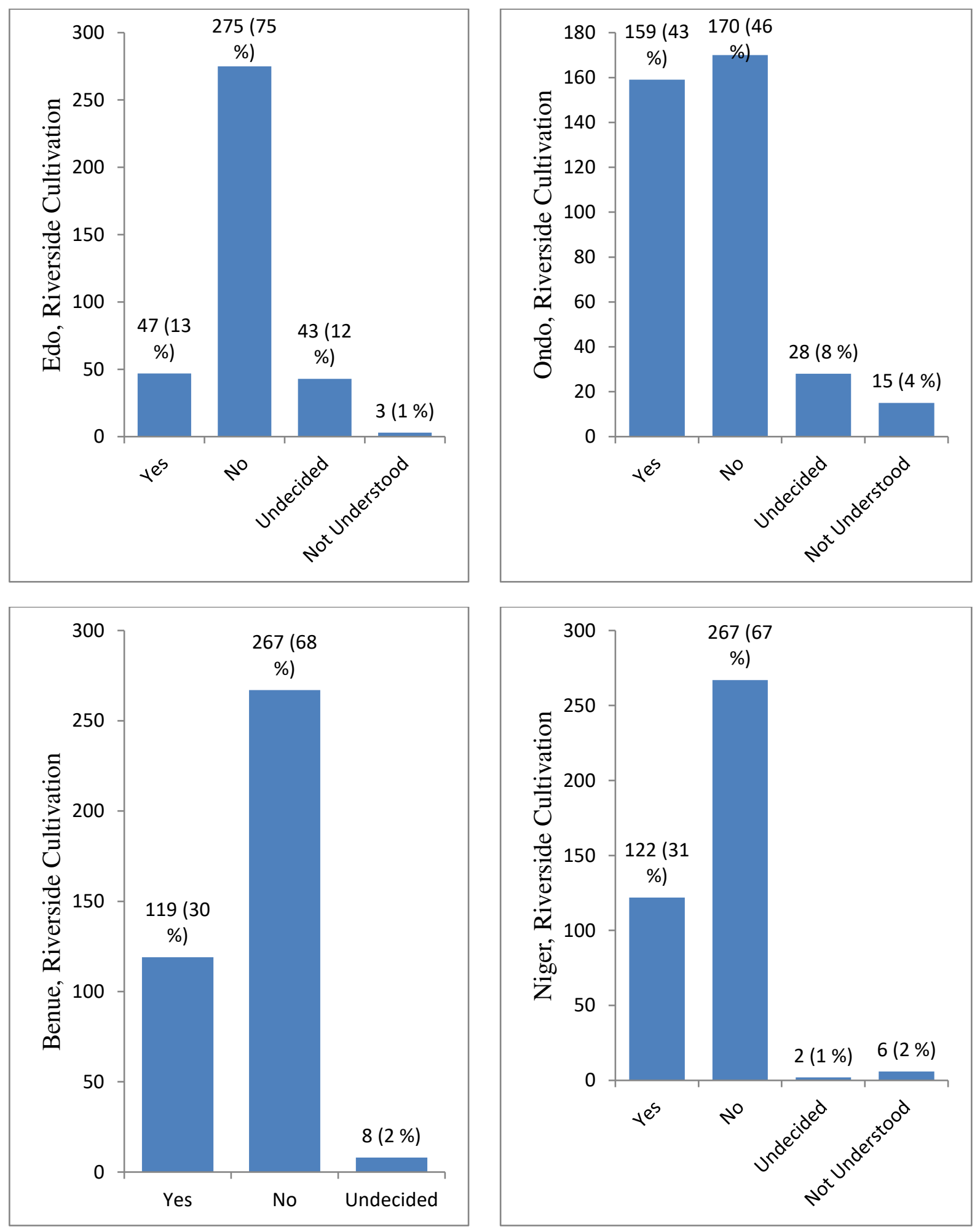

Fig. 3 Riverside cultivation across the four study states 
The ideas of covering farmland with plants remnant as a source of green water strategy were observed to be highly adapted with 86, 76, 74 and $66 \%$ in Benue, Ondo, Edo and Niger state respectively (Fig. 4). Rotten plant debris would restore mineral nutrients to the soil with fertility improvement. For the farmers to have adapted the practice indicated they viewed mulching to retain the soil's moisture contents, especially for the plants that demand water for optimal performance. The advantage becomes meritorious when there is a shortage of water supply and rainfall distribution, especially in the current climate change situation. Limited natural water resources and variable rainfall threaten farmers with the negative influence, which could be alleviated with mulching as a water conservation strategy (Stelli et al. 2018).

Covering the soil with plant remnants checkmates the critical concern in the face of the lingering collective effects instigated by increasing population, high protein demand from the affluent societies, water misuse in many river basins and increasingly variable hydrological conditions fluctuation owing to climate change (Rockström et al. 2009; Rost et al. 2010). The roles of mulching as water-conserving, soil and weed management practice cannot be limited to retaining soil moisture, enhancing soil structure, maintaining soil temperature. However, mulching materials could develop roots and growth as weed, thereby competing for available nutrients, especially in the rainy periods (Patil et al. 2013). Various ways to classify mulching are surface, vertical, Polythene, Pebble and dust with peculiar advantage (Yadahalli et al. 2011). Mulching is promoted for agricultural systems (Kumar and Dey 2011) as an effective cropping technique to save water and moderate soil temperature (Zegada-Lizarazu and Berliner 2011) and enhance crop performance and weed control (Campiglia et al. 2010).

\subsection{Regression analysis of the strategies to water management adaptation}

The four adaptation strategies (independent variables, IVs) on water management are practice irrigation, change irrigation schedule, riverside cultivation, and mulching (Table 1). From the four IVs, riverside cultivation, irrigation practice and mulching were variables entered by the model for Benue State to predict the influence of the biodata on the chosen strategies. Irrigation practice was considered in Edo, mulching in Niger while riverside cultivation in Ondo State. These indicated that three IVs entered the model in Benue State were each useful in the other three states. Thus, change the irrigation schedule was not useful at all. The model summary and overall fit statistics of the model showed that the Benue State had 0.119 adjusted $\mathrm{R}^{2}$ and $0.125 \mathrm{R}^{2}$ indicating the linear regression explained $12.5 \%$ variance. 

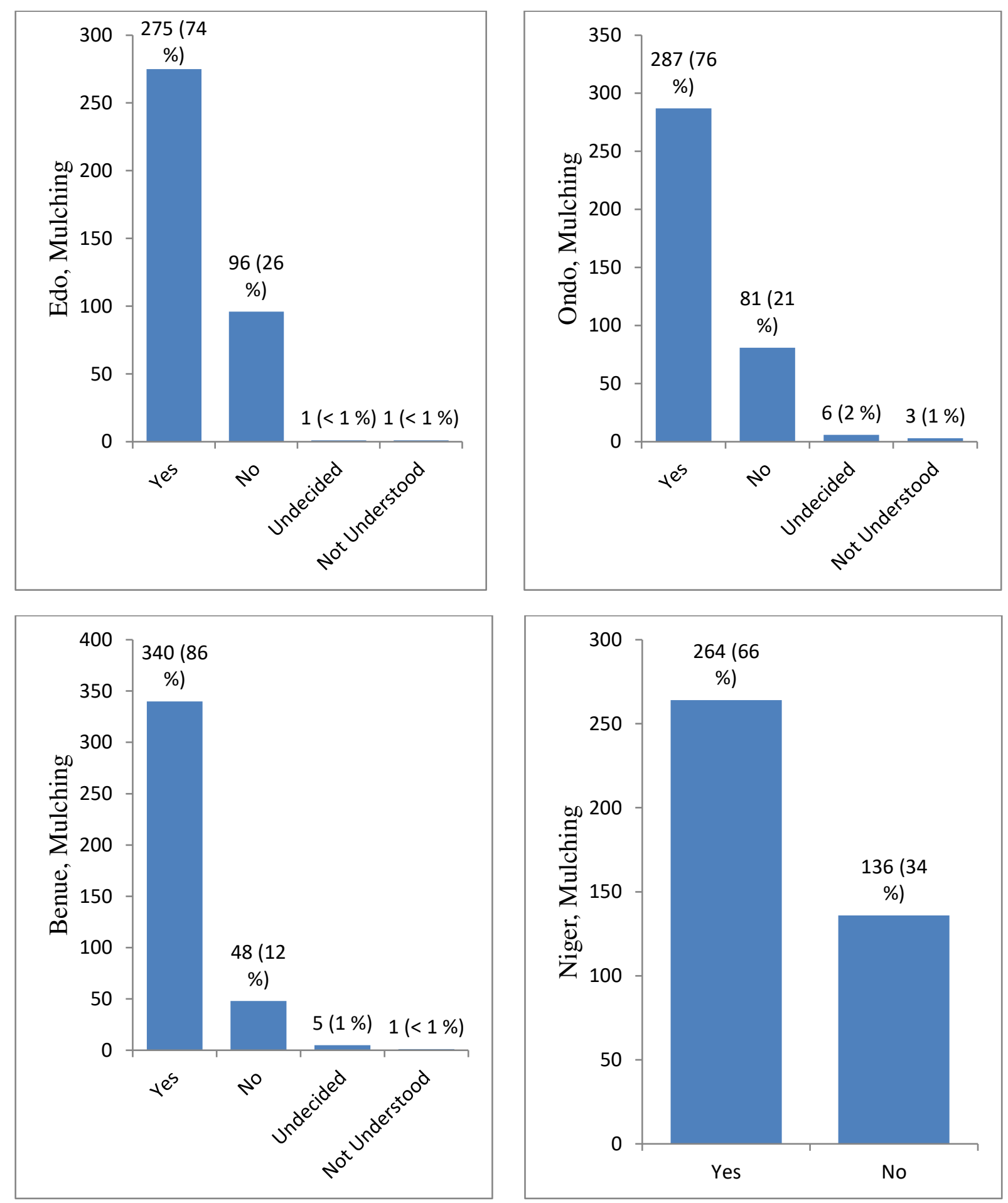

Fig. 4 Mulching adaptation across the four study states 
Table 1 Water management strategies with multiple regression analysis (Stepwise Method)

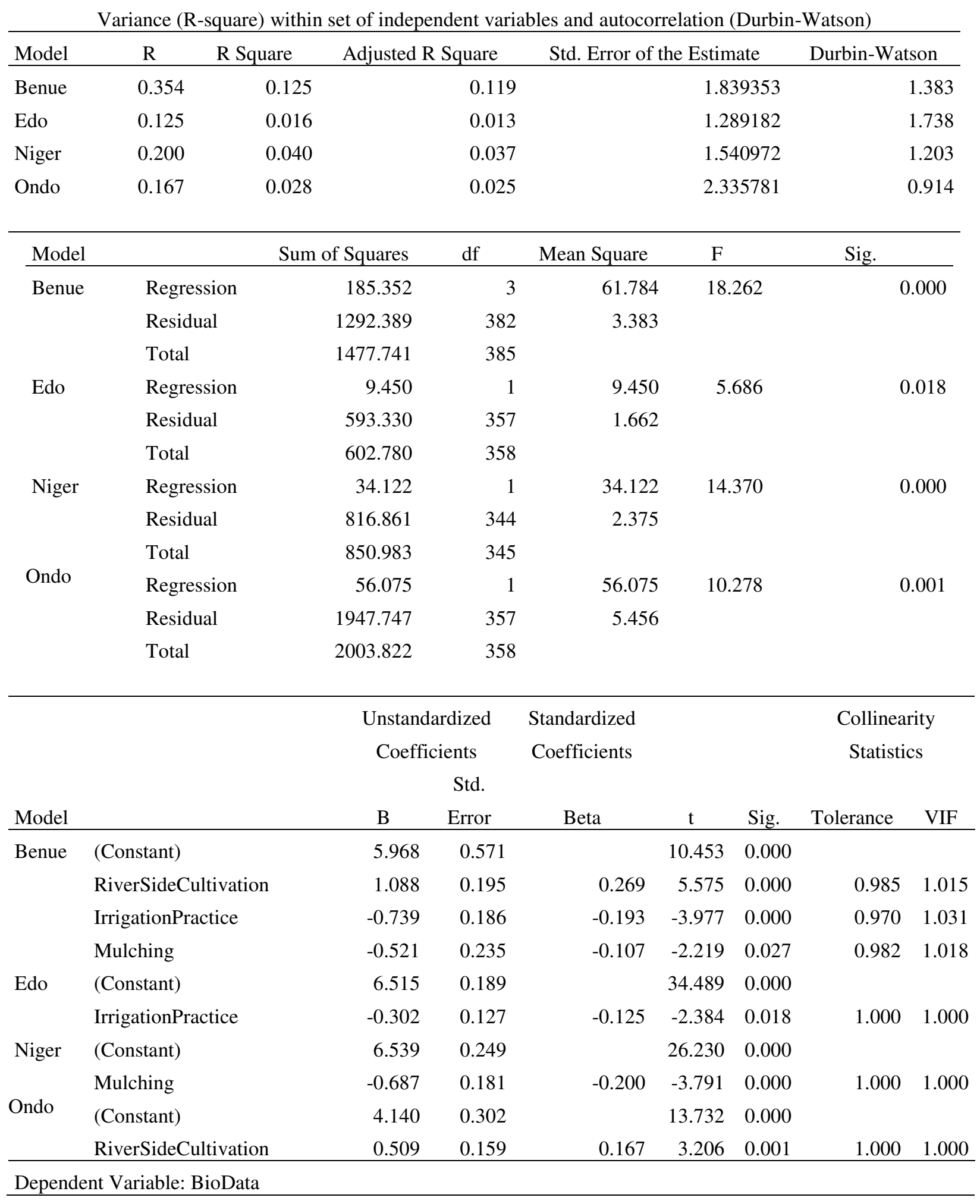


The Durbin-Watson (D.W.) value of 1.383 was less than 2 to mean positive autocorrelation, indicating a similarity in the information provided by the respondents. Showing that the significance level is less 0.05 , the sample data across the four study states provided satisfactory evidence to conclude that the regression models fit the data. It meant that the independent variables (IVs) across the models improved the fit, and the models of all the states were significant. Order of the F-values was $18.262>14.370>10.278>5.686$ across Benue, Niger, Ondo and Edo respectively. The multiple linear regression equation across the four states are as shown below, respectively

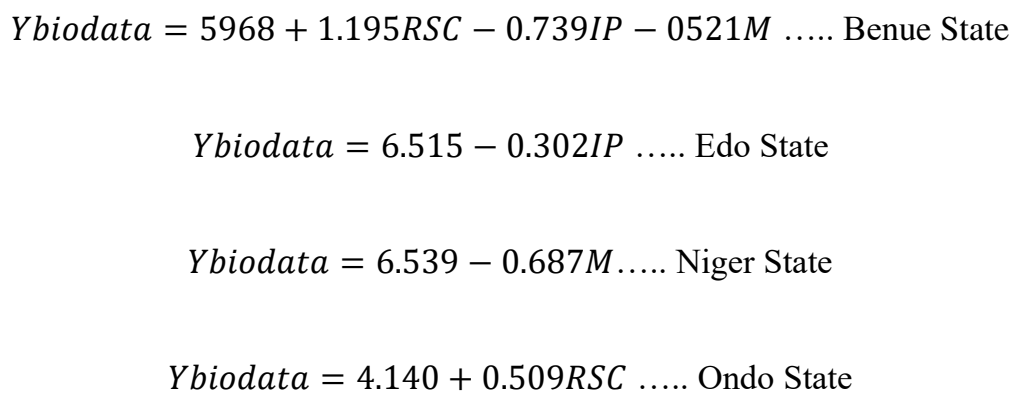

The three IVs (riverside cultivation, RSC; irrigation practice, I.P.; and mulching, M) entered by the model were highly significant. A unit increase in the influence of Benue State farmers' biodata increased the RSC by 1.195 while decreased I.P. and M by 0.739 and 0.521 , respectively. The beta values showed that RSC was considerably significant in Benue (0.269) and Ondo (0.167). However, a unit increase in the farmers' biodata across Edo, Niger and Ondo state would cause a decrease in I.P. and M. by 0.302 and 0.687 , respectively but an increase (0.509) in RSC. The results further showed high inter-correlations or associations within the variables entered into all the multiple linear regression equations that conformed to the stipulated conditions: Tolerance $>0.1$ or its reciprocal (variance inflation factor), VIF > 1.0.

\subsection{Descriptive analysis of the strategies to crop varieties adaptation}

Results of the respondents indicated that a high percentage of farmers in Niger (83\%) and Benue (73\%) engaged in selecting different technology compared to their counterparts in Ondo (53\%) and Edo (46\%) (Fig. 5). The observation from the study was that the objectives to be achieved by the farmers dictate the different techniques they adopt. Adopting the new approach is necessary as many smallholder farmers have low yields at harvest because of the crude methods accustomed to (Muzari et al. 2012). 

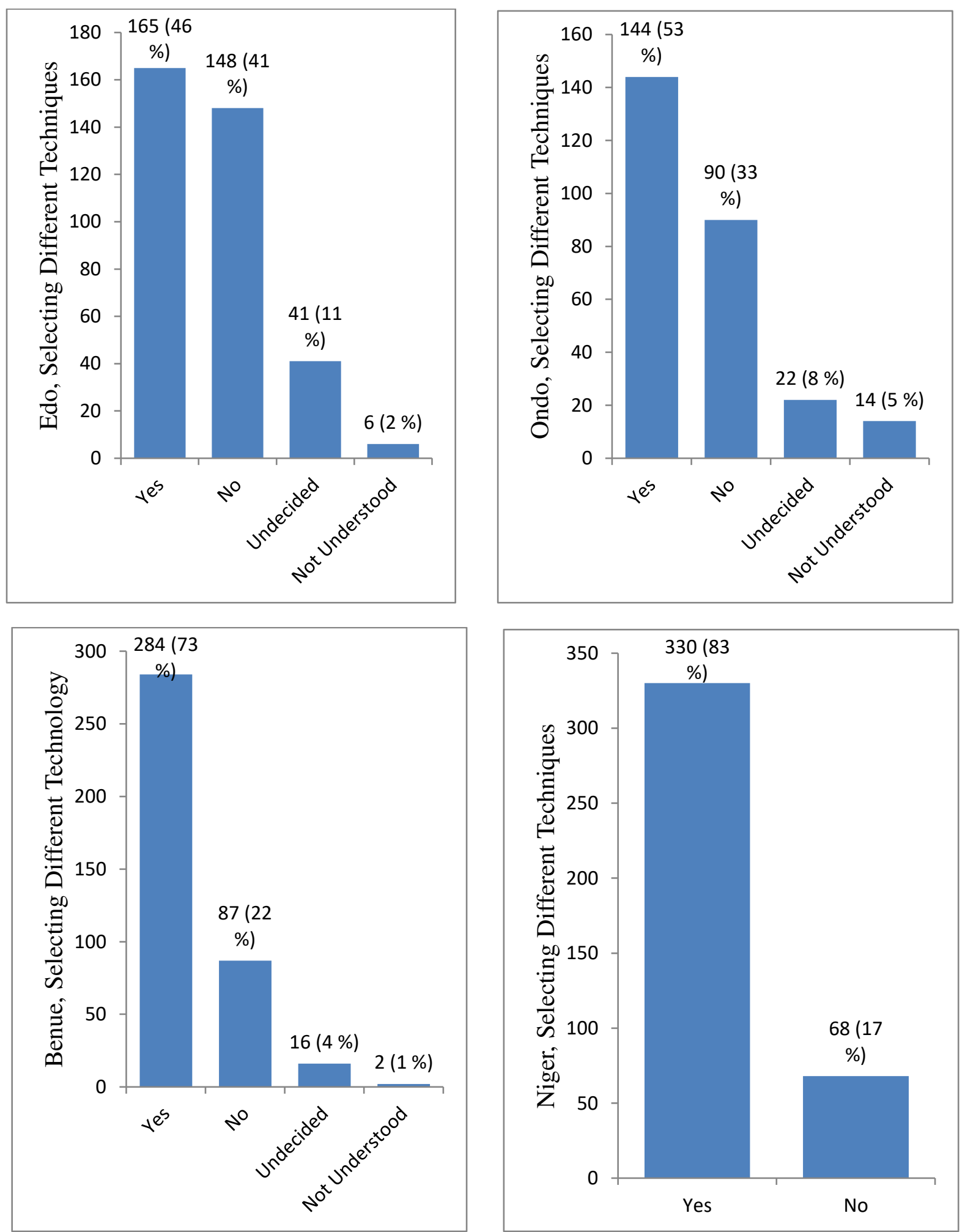

Fig. 5: Selecting different technology by the respondents across the study states 
Having itemized the reasons to come from no fertilizer and pest control usage and reliance on rain-fed agriculture, Challa (2013) examined changes to farming produce from the adaptation of modern agricultural techniques. Loevinsohn et al. (2013) said that the most common areas of technology development for farm inputs are not limited to developing new varieties and management, soil management for fertility, weed and pest control, irrigation, and water management for sustainability. Kariyasa and Dewi (2011) observed that improved techniques had a landmark in the agricultural sector. Different selected techniques to raise farm productivity and boost growth are attainable through the developed high-yield crops against the soil fertility reduction, increasing irrigation for water management, reducing the use of appropriate fertilizers without threats of residual effects, and improving market access, regulations and governance to thrive despite the competition. Other routes to attain the selected techniques are using information technology for weather-threatening management and newly adapted input selection and adopting genetically modified crops to avert pest invasion and dormancy. Reforming land ownership with productivity to define property rights and land disputes and setting up integrated agricultural value chains to create avenue and ideas for both food and cash crops are also inclusive (Jones 2015). Despite selecting different techniques to improve agriculture, Simtowe (2011) observed its slow adaptation.

Respondents in Benue (94\%), Edo (85\%), Niger (80\%) and Ondo (78 \%) showed the informed ideas of cultivating high yielding crops, respectively (Fig. 6). The responses indicated that their optimal productivity in farmland relies on choosing an appropriate and latest recommended variety to avoid low productivity even when adequate inputs are applied. It seemed that the farmers were aware of the genetically modified crops that can increase farming productivity to meet the demand for food supply, minimize money and pesticide usage, and have increased harvests to save water and scarce farmstead in the periods of climate change on farming. The objectives of every farming activity are to produce high tonnes of yield for marketability and profitability. Achieving such an objective provides a great relief with an impressive increase in food grain production, primarily due to improved crop varieties capable of exploiting the environment so provided and other components. An improved environment with genetically inferior varieties beyond a specific limit cannot lead to better yields. In contrast, enhanced crop varieties exhibit an essential role in enhancing the productivity of any crop and alone can provide nearly one-quarter to increased productivity in constant production components. 

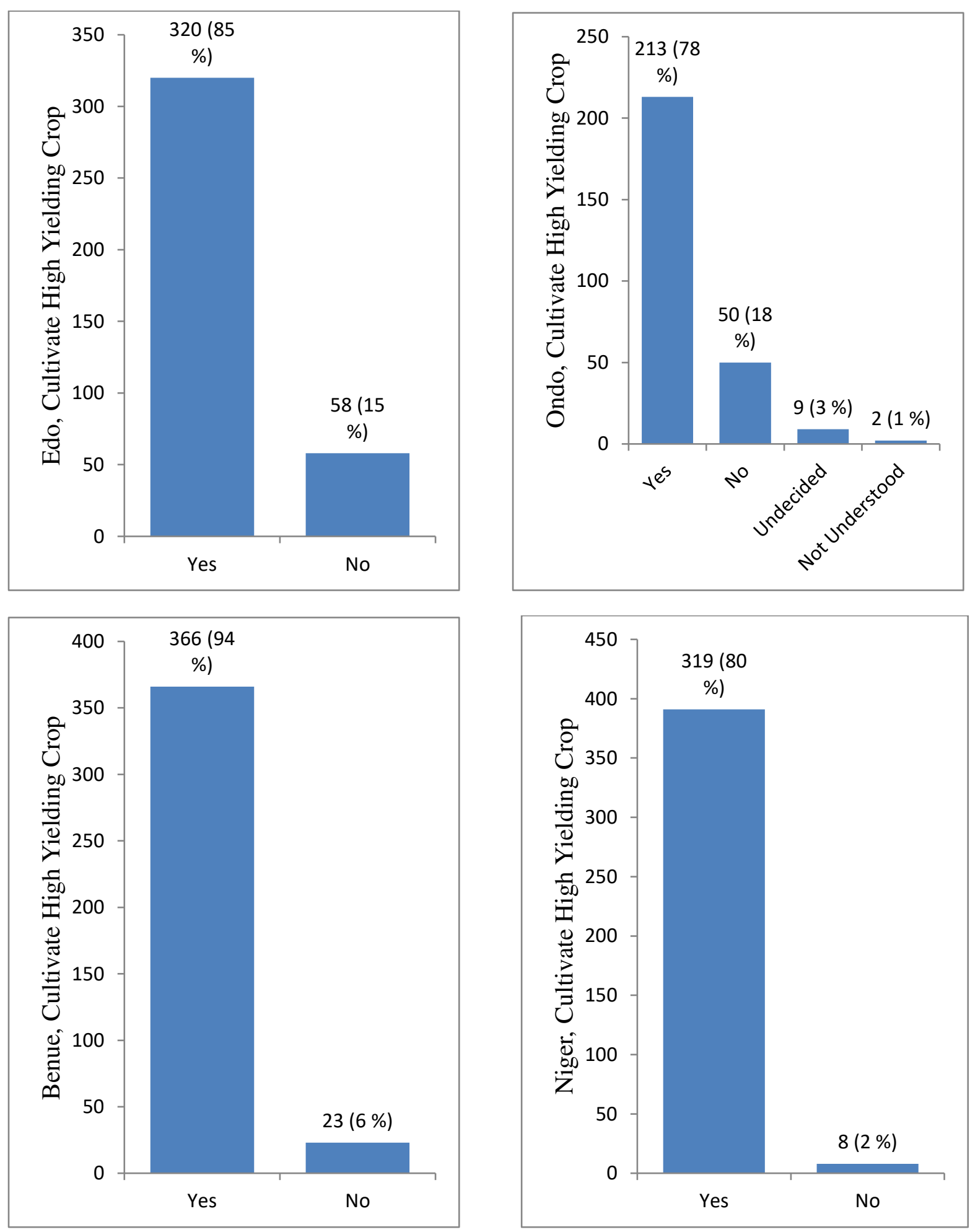

Fig. 6 Cultivate high yield crop varieties across the study states 
Manohara (2013) stipulated the suitable criteria should be across the seasons and circumstances to ascertain high yield varieties. The requirements include practising cultivation specifically for agroecological conditions, developing matured crop varieties for the planting period with good agronomic traits to meet the needs of small scale farmers, and providing crop varieties that perform well in major growing areas. The CGIAR (2017) observed that crop could exhibit high yield when the varieties planted are considered for combined resistance and tolerance with good knowledge of target agroecological zones related to climate adaptability.

Cultivation of disease-resistant varieties was high (80 \%) in Niger, followed by reducing order across Edo, Benue and Ondo with $69>66>64 \%$, respectively (Fig. 7). State with many disease-resistant varieties might indicate curbing pest invasion and disease outbreak or preventing such occurrences. The practice gives room to produce high yield crops during the harvest period and increase farmers' income. Research pointed out that varieties planted in most farmlands are not native plants and are prone to many diseases and pests (Darby 2016).

The incidence of disease outbreak and pest infestation could be averted when combined disease-resistant plants with other planting strategies to provide dynamism to the farmland. The best mitigating method involves understanding locally disturbing diseases, observing farmland for previously attacked conditions, discussing with local extension officers, finding appropriate crop varieties through their recommendations, or visiting nearby research institutes in agriculture. Rice, wheat, maize and banana are the most constantly threatened crops (Fisher et al. 2012). Additional techniques to disease resistance on farmland include grafting against soil-borne diseases, replacing shallow with deep watering to potentiate root growth more profound into the soil for more robust and larger plants produce, thinning for aeration and drying between each watering, removal of the infected plants and debris, and crop rotation to checkmate pest and disease attack (Darby 2016).

Usage of mutants as models for plant immune boosting reveals a detailed and deep understanding of various contributors, identifies the core components of defence response for future breeding of durable and sustainable disease resistance of seeds (Piquerez et al. 2014). Working on disease-resistant varieties helps against vector-borne disease and boosts yields (Dangl et al. 2013). 

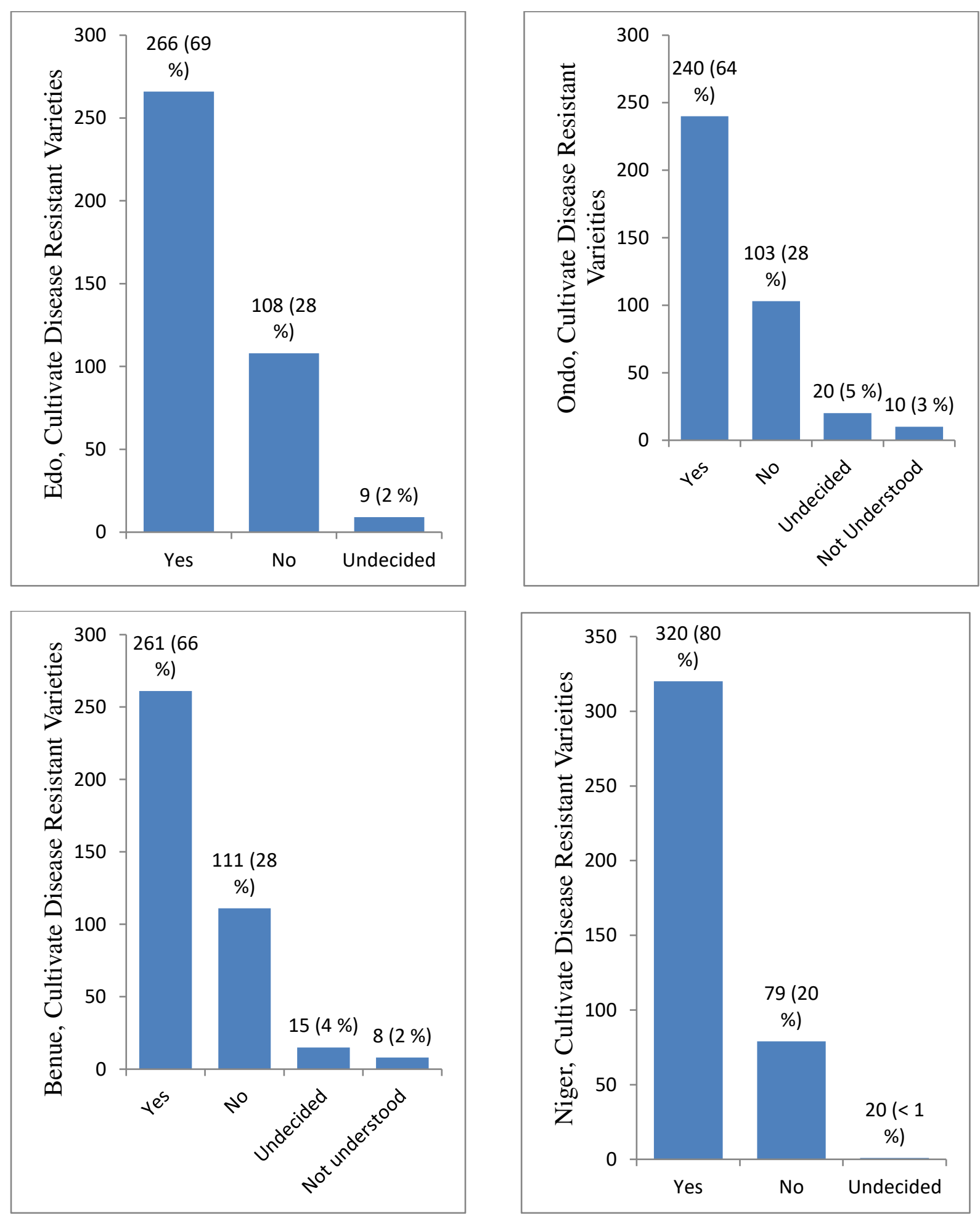

Fig. 7 Cultivate disease resistant varieties across the study states 
Cultivating drought-resistant crops across the study areas followed $71>53>49>47 \%$ in Niger, Benue, Ondo and Edo state, respectively (Fig. 8). The farmers were aware of the water shortage to get crops that can thrive in such a situation. The idea would foster the farmers to grow and produce crops all year round despite the limited water availability. Indication of drought is poor soil, which collectively inhibits crop productivity. Farmers can experience yield losses, decreased productivity and food insecurity, malnutrition and even famine in the climate change effects era from the drought. Mikhailova (2019) clarified that Namibian farmers currently cultivate crop varieties of cowpea and sorghum that perform better with tolerance to drought and pests. Drought is common in the region of Africa, and the weather is becoming unpredictable. Most affected areas hardly adopt irrigation-fed technology or agricultural practices, thereby relying on rainfall, affecting optimal productivity and yields from its random occurrence. The last two decades have experienced drought tolerance research to produce staple crops like maize, rice and wheat (Ngumbi 2020). The author buttressed that breeding and bringing drought-resistant crops to market takes time, field trial to characterize for the required traits across several locations, a considerable amount of money needed to produce, and the need to restock for potency and viability are parts of the lingering challenges. The advantage outweighs the demerits. Drought is one of the abiotic stresses and critical environmental factors that derogatorily affects plant growth and development (Kosova et al. 2019). Genotype and environment with water deficit stress affect plant response (Vitamtas et al. 2015). A shift from aerobic to less-efficient anaerobic metabolism or a coping strategy to avoid enhanced reactive oxygen species formation could occur, thereby stimulating progressive oxidative damage and cell death.

Response to cultivate water-resistant crops was only affirmed in Ondo state with $41 \%$ while the other three states marked "No" with $76>72>57 \%$ in Niger, Benue and Edo, respectively (Fig. 9). Deduction from the percentage of the respondents implied that the soil of the study areas might not be saturated. Submergence or flood is a significant detrimental abiotic stress in the low-lying regions where crop losses due to waterlogging are considerably high (Ahmed et al. 2013). The authors discovered a new, more effective technique to identify genomic areas of crops under waterlogged stress for comprehensive molecular linkage maps, thereby enabling a pyramid of desirable traits to improve crop submergence tolerance through marker-assisted selection. The probable conditions are either waterlogging when roots and portions of shoot are underwater or submergence when the entire plant is water-covered. 

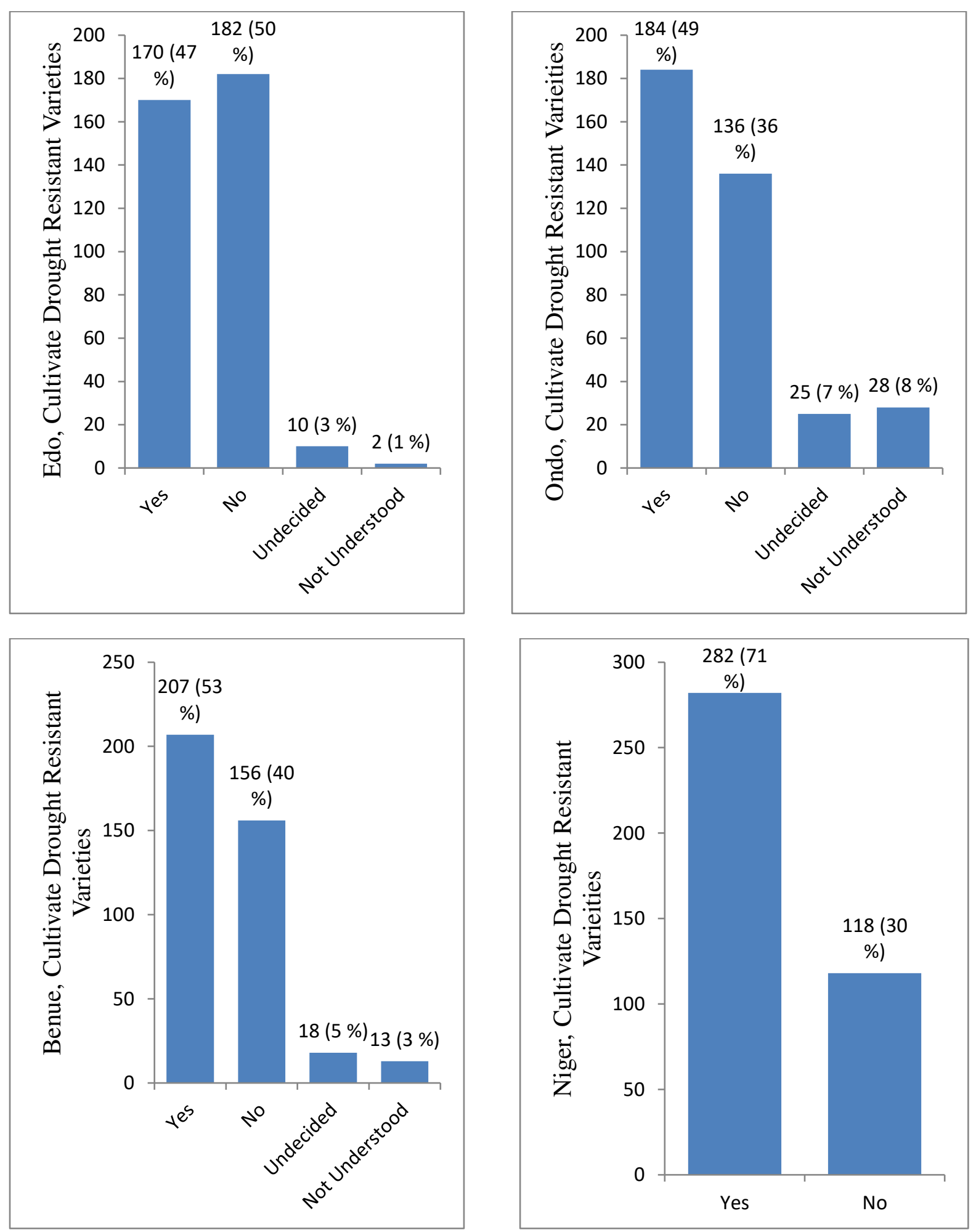

Fig. 8 Cultivate drought resistant varieties across the study states 

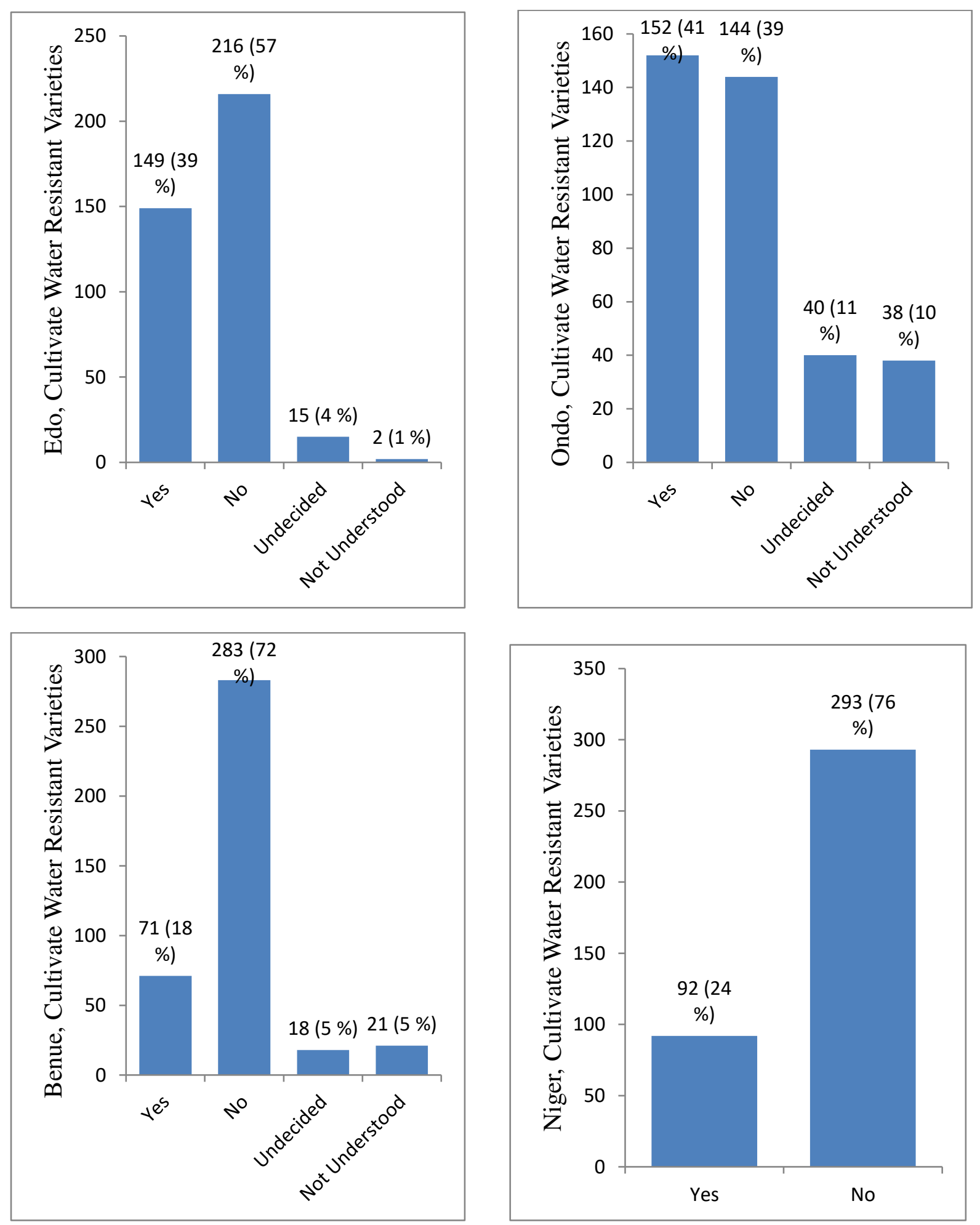

Fig. 9 Cultivate water resistant varieties across the study states 
Some effects that are not limited to depletion of chlorophyll, protein and RNA degradation, reduction of levels of nutrients such as nitrogen, phosphorus, metal ions, and minerals in plants shoot linked to waterlogging (Buchanan-Wollaston et al. 2003). Root rot disease hindered plants' growth and increased product yield loss during and after the flooding (Schmitthenner 1995). Retardation in root and shoot development accompanied by reduced yields and dry matter accumulation are other possible effects (Malik et al. 2002). Flooding affects crop yields and growth across the world (Oosterhuis et al. 1990). Oxygen and the accompanied nutrient and mineral uptake inhibition and inability to cope with oxidative stress are why waterlogging has detrimental effects on plant performance (Alamgri and Uddin 2011).

\subsection{Regression analysis of the strategies to crop varieties adaptation}

The five independent variables (IVs) for the adaptation strategies on crop varieties are selecting different technology, cultivating high yield varieties, cultivating disease-resistant varieties, cultivating drought-resistant varieties, and cultivating water-resistant varieties. Four IVs (except cultivating disease-resistant varieties) were resulted to enter into the model as the valuable variables for the biodata influence in Benue State (Table 2). Growing drought-resistant varieties was the only IV the model entered to predict the impact of biodata in Edo State. Cultivation of both waterand drought-resistant varieties were the two IVs the model recognized as the influence of respondents biodata in Niger State. In contrast, the cultivation of disease-resistant varieties was the IV considered by the model for the multiple linear regressions in Ondo State. The indication was that the respondents highly viewed the respondents' cultivation of drought-resistant varieties to curb the menace of the climate change threats on crop survival across the study states except for Ondo. The summary and overall fit statistics indicated that the Benue State model had 0.082 adjusted $\mathrm{R}^{2}$ with $0.092 \mathrm{R}^{2}$ to imply that the regression model explained $9.20 \%$ variance. In comparison, 0.026 adjusted $\mathrm{R}^{2}$ with $0.029 \mathrm{R}^{2}$ indicated that the Ondo State regression model explained $2.90 \%$ variance. The 0.213 adjusted $\mathrm{R}^{2}$ with 0.217 $\mathrm{R}^{2}$ showed the Niger State regression model explained $21.70 \%$ variance, while the adjusted $0.012 \mathrm{R}^{2}$ with $0.016 \mathrm{R}^{2}$ implied that the Ondo State regression model explained $1.60 \%$ variance. The Durbin-Watson (D.W.) value $(<2)$ showed a positive correlation in the data of the multiple linear regression of each state and the order of strength followed $0.891>1.316>1.516>1.801$ across Ondo, Benue, Niger and Edo State, respectively 
Table 2: Crop Resistant Varieties with Multiple Regression Analysis (Stepwise Method)

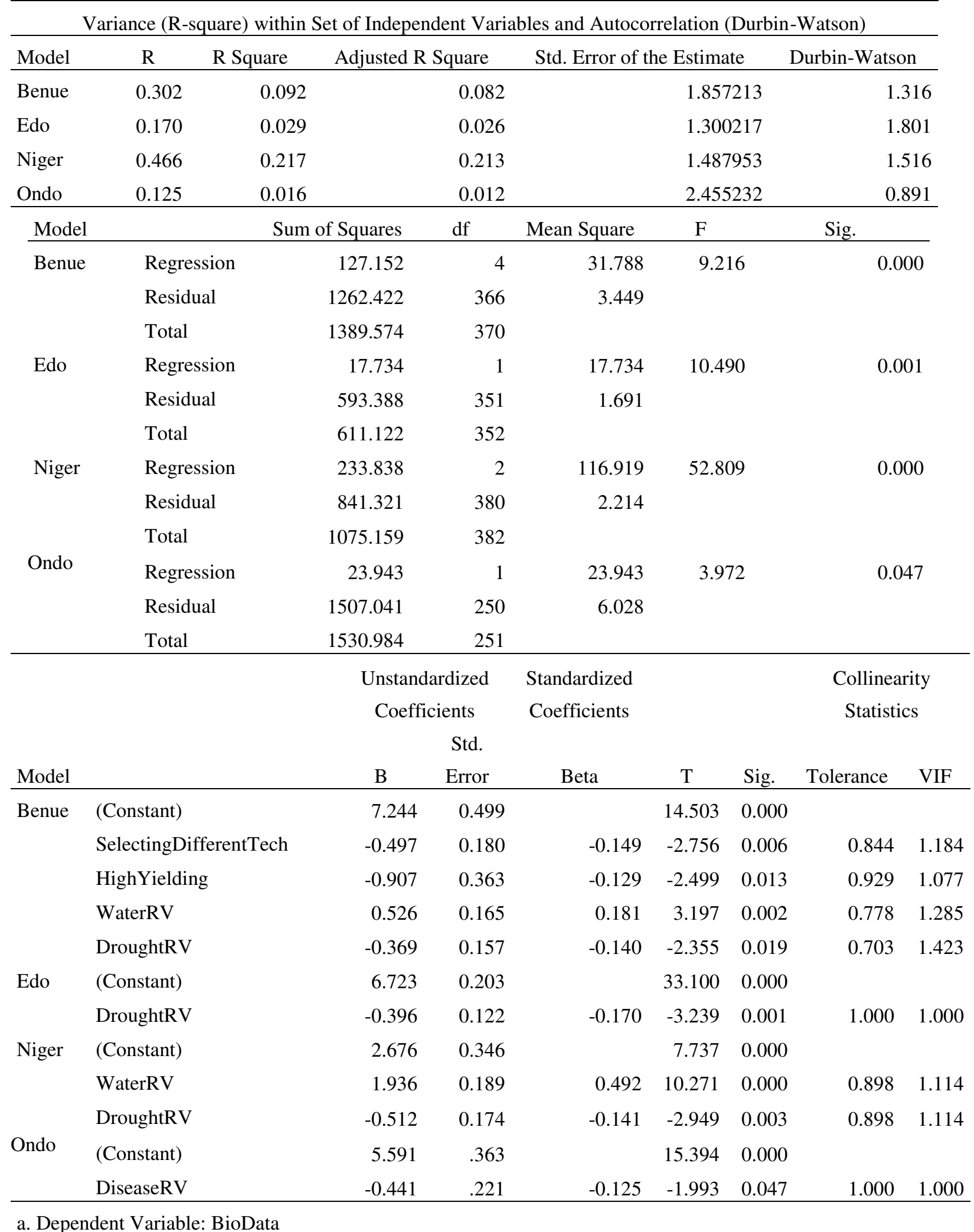


The null hypothesis stipulated that the model should explain zero variance $\left(\mathrm{R}^{2}=0\right)$ in the dependent variables of the respondents' strategies for modified seeds. The F-test results were highly significant $(\mathrm{p}<0.000)$ with the F value being 9.216, 10.490 and 52.809 in Benue, Edo and Niger respectively while $p=0.047<0.05$ in Ondo State. The deduction from the significance levels was that the model explained a significant amount of variance in the influence of dependent variable (biodata) on the respected chosen IVs into the multiple linear regression model of the various state's strategies for modified seeds.

For the exact number of ways that the modified seed strategies (independents variables; IVs) are affected by the influence of the biodata of the respondent and levels of significance within such variables, the applicable multiple linear regression equation across the four states are

$$
\begin{gathered}
\text { Ybiodata }=7.244-0.497 S D T-0.907 H Y V+0.526 W R V-0.369 D R V \ldots . . \text { Benue State } \\
\text { Ybiodata }=6.723-0.396 D R V \ldots . . \text { Edo State } \\
\text { Ybiodata }=2.676+1.936 W R V-0.512 D R V \ldots . . \text { Niger State } \\
\text { Ybiodata }=5.591-0.441 D R V \ldots . . \text { Ondo State }
\end{gathered}
$$

The Benue model comprised the four IVs (selecting different technology, cultivating high yield varieties, cultivating water-resistant varieties, and cultivating drought-resistant varieties). However, the beta value indicated growing water-resistant varieties to be more significant than any other IVs the model entered. The only IV (droughtresistant varieties) entered into the Edo model was significant. Two IVs (cultivating water and drought-resistant varieties) had a high impact on the farmers' responses in Niger State. Though they were highly significant, the beta value (0.492) indicated cultivating water-resistant varieties had a higher effect under the standardized coefficients. The only IV entered by the Ondo model was growing disease-resistant varieties and was significant. The results showed high inter-correlations or inter-association within the variables entered into all the multiple linear regression equations that conformed to the stipulated conditions: Tolerance $>0.1$ or variance inflation factor, VIF > 1.0. 


\section{Conclusions and recommendations}

The research descriptively found that mulching among the water management was favourably adapted unlike the other three. Highest $\%$ of farmers did not adapt drought- and water- resistant varieties except in Edo and Ondo State respectively.

The stepwise multiple linear regression entered three WMS (water management strategies: riverside cultivation, irrigation practising and mulching) and also four CRV (crop resistant varieties, except DiRV: diseaseresistant varieties) into the model for Benue State. Drought-resistant varieties was entered for the model of Edo, waterand drought-resistant varieties for Niger, but DiRV for Ondo state. However, change the irrigation schedule was not helpful for any of the models. The highest variance in the model occurred in the Benin State (12.5\% for WMS) and Niger State (21.7\% for CRV) respondents.

The Durbin-Watson values $<2$ across the study states indicated positive autocorrelation and similarity in the farmers' responses. The $p$-value $<0.05$ for the overall sample data across the study states showed that the models fit the data while $t$-values showed significant influence on riverside cultivation in Benin and Ondo States for the WMS.

The Agricultural Development Programme across the nation ought to craft their strategies around water management adaptation to abate the unexpected dry-spell scenarios associated with the climate change effects for the farmers to be productive over the farming year. Such a campaign would make farmers see that mulching is not the only water management strategy. In addition, both dry and water resistant varieties have to be introduced to the farmers across the study four areas, and probably throughout the nation.

\section{Declarations}

Funding: The funding source was through the $\mathrm{PhD}$ research grant given to the first and corresponding author, $\mathrm{Mr}$ Adeleke Taofik TOWOLAWI of $3^{\text {rd }}$ Cohort: PG 09/ 0181 of Environmental Systems and Climate Change Programme in the Centre of Agricultural Development and Sustainable Environment (CEADESE) of World Bank, Federal University of Agriculture, Abeokuta, PMB 2240, Ogun State, Nigeria.

Competing interests: The authors have no conflicts of interest to declare. 
Availability of data and material: The datasets generated and or analyzed during the current study are not publicly available due to being a property of the World Bank CEADESE of FUNAAB, Ogun State, Nigeria but are available from the corresponding author on reasonable request and CEADESE approval.

Code availability: Not applicable

Authors' contributions: Conceptualization: Olusegun Oguntoke, Babatunde S. Bada and Joseph O. Adejuwon; Methodology: Adeleke Taofik Towolawi; Formal analysis and investigation: All the authors; Writing - original draft preparation: Adeleke Taofik Towolawi; Writing - review and editing: Olusegun Oguntoke, Babatunde S. Bada and Joseph O. Adejuwon; Funding acquisition: Adeleke Taofik Towolawi; Resources: Adeleke Taofik Towolawi; Supervision: Olusegun Oguntoke, Babatunde S. Bada and Joseph O. Adejuwon; Reading and approved of the final manuscript: All authors; and Submission of the manuscript: Adeleke Taofik Towolawi.

Ethics Approval: Not Applicable

Consent to participate: Not Applicable

Consent to publish: All the authors approved publication of this paper as our research outcome.

\section{Acknowledgements}

I am grateful to the World Bank through its African Centre of Agricultural Development and Sustainable Environment (CEADESE) in the Federal University of Agriculture Abeokuta (FUNAAB) for the research grant: PG 09/ 0181. My institution, FUNAAB, is appreciated for its outstanding performance as the World Bank African Centre of Excellence. I appreciate both Prof. O. D. Akinyemi (the CEADESE Director) and Prof. O. S. Awokola (the Leader of my programme, Environmental Systems and Climate Change). I am also appreciative of the Agricultural Development Programme across Benue, Edo, Ondo, and Niger States for their assistance to meet the farmers. Lastly, I thank Olaide Khadijat, Rooreromi Qanita and Ooreoluwa Yasir for their data coding and analysis. 


\section{References}

Adaikwu A, Ali,A, Agber P (2017) Characterization and classification of soils from selected areas in Benue State, Southern Guinea Savanna of Nigeria. Asian Journal of Plant and Soil Sciences 2(1):17-24.

Adegbite KA, Okafor ME, Adekiya AO, Alori ET, Adebiyi OTV (2019) Characterization and classification of soils of a toposequence in a derived savannah agroecological zone of Nigeria. The Open Agriculture Journal 13:44-50.

Ahmed F, Raffi MY, Ismail MR, Juraimi AS, Rahim HA, Asfaliza R Latif MA (2013) Waterlogging tolerance of crops: breeding, mechanism of tolerance, molecular approaches, and future prospects. Hindawi Publishing Corporation. BioMed Research International Article ID 963525: 10 pp. http://dx.doi.org/10.1155/2013/963525.

Alamgir H, Uddin SN (2011) Mechanisms of waterlogging tolerance in wheat: morphological and metabolic adaptations under hypoxia or anoxia. Australian Journal of Crop Science 5(9): 1094-1110.

Amujoyegbe BJ (2012) Farming system analysis of two agroecological zones of Southwestern Nigeria. Agricultural Science Research Journal 2(1):13 - 19.

Arbuckle Jr JG, Morton LW, Hobbs J (2015) Understanding farmer perspectives on climate change adaptation and mitigation: the roles of trust in sources of climate information, climate change beliefs, and perceived risk. Environment and Behaviour 47(2):205-234.

Bates BC, Kundzewicz ZW, Wu S, Palutikof JP (2008) Climate Change and Water. Technical Paper of the Intergovernmental Panel on Climate Change (IPCC). IPCC Secretariat, Geneva, Switzerland.

Barrett CB, Swallow BM (2006) Fractal poverty traps. World Development 34:1-15.

Bekele W, Drake L (2003) Soil and water conservation decision behaviour of subsistence farmers in the eastern highlands of Ethiopia: A case study of the Hunde-Lafto area. Ecological Economics 46:437-451.

Buchanan-Wollaston V, Earl S, Harrison E, Mathas E, Navabpour S, Page T, Pink DAC (2003) The molecular analysis of Plant senescence - Agenomics approach. Plant Biotechnology Journal 1(1):3-22.

Campiglia E, Mancinelle R, Radicetti E, Caporali F (2010) Effect of cover crops and mulches on weed control and nitrogen fertilization in tomato (Lycopersicon esculentum Mill.). Crop Protect 29(4):354-363.

CAoWMiA (Comprehensive Assessment of Water Management in Agriculture) (2007) Water for food, water for life. a comprehensive assessment of water management in agriculture. Earthscan and International Water Management Institute, London, UK and Colombo, Sri Lanka.

CGIAR (Consultative Group for International Agricultural Research) (2017) Improved crop varieties and quality seed boost yields and income for smallholders. Research program on roots, tubers and bananas. https://www.rtb.cgiar.org/news/improved-crop-varieties-quality-seed-boost-yields-income/. Accessed on 18 February 2020 .

Challa M (2013) Determining factors and impacts of modern agricultural technology adaptation in West Wollega, Munich, GRIN Publishing GmbH, http://www.grin.com/en/e-book/280336/determining-factors-and-impacts-ofmodern-agricultural-technology-adaptation. Accessed on 24 January 2020.

Chebil A, Frija A, Makhlouf M, Thabet C, Jebari S (2019) Effects of water scarcity on the performances of the agricultural sector and adaptation strategies in Tunisia, Agricultural Economics - Current Issues. Kulshreshtha SN, IntechOpen, 18pp. DOI: 10.5772/intechopen.83568

Chimwanza B, Mumba PP, Moyo BHZ, Kadewa W (2005) The impact of farming on river banks on the water quality of the rivers. International Journal of Environmental Science and Technology 2(4):353-358. 
Cook HF, Valdes GSB, Lee HC (2006) Mulch effects on rainfall interception, soil physical characteristics and temperature under Zea mays L. Soil Tillage Research 91:227-235.

Dangl JL, Horvath DM, Staskawicz BJ (2013) Pivoting the plant immune system from dissection to deployment. Science 341:746-751. DOI: 10.1126/science.1236011.

Darby B (2016) 24 Disease-resistant crop varieties and strategies improve their vigour. Hobby Farms. https://www.hobbyfarms.com/24-disease-resistant-crop-varieties-strategies-improve-their-vigor/. Accessed 19 February 2020.

Díaz-Ambrona CGH, Pazos RG, Tovar COM (2004) Global Climate Change and Food Security for Small Farmers in Honduras. $4^{\text {th }}$ International Crop Science Congress, Australia. 26 September - 1 October. Australian Society of Agronomy, Brisbane, Queensland, Australia.

Dovers SR, Hezri AA (2010) Institutions and policy processes: the means to the ends of adaptation. Wiley Interdisciplinary Reviews: Climate Change 1(2):212-231.

Dzvurumi F (2008) Evaluation of emergency small scale irrigation projects. Summary notes to the powerpoint presentation. FAO-RIACSO.

El Afandi G, Khalil FA, Ouda SA (2010) Using irrigation scheduling to increase water productivity of wheat-maize rotation under climate change conditions. Chilean Journal of Agricultural Research 70(3):474-484.

Elias EH, Flynn R, Idowu OJ, Reyes J, Sanogo S, Schutte BJ, Smith R, Steele C, Sutherland C (2019) Crop vulnerability to weather and climate risk: analysis of interacting systems and adaptation efficacy for sustainable crop production. MDPI Sustainability 11:6619. DOI: 10.3390/su11236619.

FAO (Food Agriculture Organization) (2003) Unlocking the water potential of agriculture. FAO Corporate Document Repository. 260 p. FAO, Rome, Italy.

Fisher MC, Henk DA, Briggs CJ, Brownstein JS, Madoff LC, McCraw SL, Gurr SJ (2012) Emerging Fungal Threats to Animal, Plant and Ecosystem Health. Nature 484:186-194. DOI: 10.1038/nature10947.

Gu Z, Qi Z, Ma L, Gui D, Xu J, Fang Q, Yuan S, Feng G (2017) Development of an irrigation scheduling software based on model-predicted crop water stress. Computers and Electronics in Agriculture 143:208-221.

Hardlife Z, Talent M, Oswell R (2017) Streambank cultivation along Chiredzi River in Zaka District, Zimbabwe: An activity widely practiced but institutionally condemned. International Journal of Agriculture, Environment and Bioresearch 2(5):79-96.

Harrison KA (2012) Irrigation scheduling methods. The University of Georgia Publication. College of Agricultural and Environmental Sciences, College of Family and Consumers Sciences. UGA Cooperative Extension Bulletin 974: $8 \mathrm{pp}$.

Hugget R, Lindley S, Gavin H, Richardson K (2004) Physical Geography: A Human Perspective. Routledge $1^{\text {st }}$ Edition. Hodder Arnold Publication, London. 512 pp.

Imadojemu PE, Osujieke DN, Obasi SN, Mbe JO, Dibofori EG (2018) Characterization and classification of some soils of Edo State formed under different parent materials. FUW Trends in Science \& Technology Journal 3(1):201 206.

Jones M (2015) The world economic forum agenda. The world economic forum on Africa. Cape Town, South Africa from 3-5 June. https://www.weforum.org/agenda/2015/06/8-ways-africa-can-raise-farm-productivity-and-boostgrowth/. Accessed on 23 January 2020. 
Kariyasa K, Dewi A (2011) Analysis of factors affecting adaptation of integrated crop management farmer field school (ICM-FFS) in Swampy Areas. International Journal of Food and Agricultural Economics 1(2):29-38.

Khalil FAF, Tammam AM, Amin IA, Mohamed KA (2006) Scheduling irrigation for some wheat cultivars under upper Egypt conditions. Mansoura University Journal of Agricultural Sciences 31:561-572.

Kosová K, Vítámvás P, Klíma M, Prášil IT (2019) Breeding drought-resistant crops: G×E interactions, proteomics and pQTLS. Journal of Experimental Botany 70(10):2605-2608. DOI: 10.1093/jxb/erz116.

Kumar S, Dey P (2011) Effects of different mulches and irrigation methods on root growth, uptake, water-use efficiency and yield of strawberry. Science Hort. 127:318-324.

Lipper L, Thornton P, Campbell BM, Baedeker T, Braimoh A, Bwalya M, Caron P, Cattaneo A, Garrity D, Henry K, Hottle R, Jackson L, Jarvis A, Kossam F, Mann W, McCarthy N, Meybeck A, Neufeldt H, Remington T, Sen PT, Sessa R, Shula R, Tibu A, Torquebiau EF (2014) Climate-smart agriculture for food security. Nature Climate Change 4:1068-1072.

Loevinsohn M, Sumberg J, Diagne A (2012) Under what circumstances and conditions does the adaptation of technology result in increased agricultural productivity? Protocol. London: EPPI Centre, Social Science Research Unit, Institute of Education, University of London.

Lok JYJ (2015) Cover crop impacts on soil quality during miscanthus $x$ giganteus establishment in central Iowa. Theses, Iowa State University. 14963. https://lib.dr.iastate.edu/etd/14963. 57pp.

Long NV, Assefa Y, Schwalbert R, Ciampitti IA (2017) Maise yield and planting date relationship: A synthesisanalysis for U.S. high-yielding contest winner and field research data. Frontiers in Plant Science 8 (Article 2106), 9pp. doi:10.3389/fpls.2017.02106.

Malik AI, Colmer TD, Lambers H, Setter TL, Schortemeyer M (2002). Short-term waterlogging has long-term effects on the growth and physiology of wheat. New Phytologist 153(2):225-236.

Manohara KK (2013) Selection of high yielding varieties in different crops for improved profitability. Agropedia. http://agropedia.iitk.ac.in/content/selection-high-yielding-varieties-different-crops-improved-profitability. Accessed on 18 February 2020.

MEA (Millennium Ecosystem Assessment) (2005). Ecosystems and human well-being: wetlands and water synthesis. World Resources Institute, Washington, D.C., USA.

Mikhailova N (2019) Drought-tolerant crops to contribute to food security in Namibia. Office of Public Information and Communication, International Atomic Energy Agency. https://www.iaea.org/newscenter/news/drought-tolerantcrops-to-contribute-to-food-security-in-namibia. Accessed on 19 February 2020.

Mucina L, Rutherford MC, Powrie LW (2006) The logic of the map: Approaches and procedures. In: The Vegetation of South Africa, Lesotho and Swaziland. Strelitzia 19. South African National Biodiversity Institute, Pretoria. ISBN 13: 978-1-919976-21-1.

Muzari W, Gatsi W, Muvhunzi S (2012) The impacts of technology adaptation on smallholder agricultural productivity in sub-saharan Africa: A Review. Journal of Sustainable Development 5(8):69-77.

Ngumbi E (2020) Becoming drought resilient: Why African farmers must consider drought-tolerant crops. Opinion. Inter Press Services News Agency. http://www.ipsnews.net/2019/03/ becoming-drought-resilient-why-africanfarmers-must-consider-drought-tolerant-crops/. Accessed on 19 February 2020. 
NIWA (2016) Farm practices and stream health. NIWA Taihoro Nikurangi. https://niwa.co.nz/ourscience/freshwater/tools/shmak/manual/10manage. Accessed on 21 February 2020.

Ojanuga AG (2006) Agroecological zones of Nigeria manual. FAO/NSPFS, Federal Ministry of Agriculture and Rural Development, Abuja, Nigeria, Pp. 32-37.

Oosterhuis DM, Scott HD, Hampton RE, Wullschleger SD (1990) Physiological responses of two soybean [Glycinemax (L.) Merr] cultivars to short-term flooding. Environmental and Experimental Botany 30(1):85-92.

Patil SS, Kelkar TS, Bhalerao SA (2013) Mulching: A soil and water conservation practice. Research Journal of Agriculture and Forestry Sciences 1(3):26-29.

Piquerez SJM, Harvey SE, Beynon JL, Ntoukakis V (2014) Improving crop disease resistance: Lessons from research on arabidopsis and tomato. Frontiers in Plant Science 5(Article 647): 13pp. https://doi.org/10.3389/fpls.2014.00671.

Queensland Government (2006) Stream bank planting guidelines and hints. Department of natural resources and water. Queensland. http://www.nrw.gld.gov.au. Accessed on 21 December 2020.

Räsänen A, Juhola S, Nygren A, Käkönen M, Kallio M, Monge AM, Kanninen M (2016) Climate change, multiple stressors and human vulnerability: A systematic review. Reg Environmental Change 16:2291-2302.

Raza A, Razzaq A, Mehmood SS, Zou X, Zhang X, Lv Y, Xu J (2019) Impact of climate change on crops adaptation and strategies to tackle its outcome: a review. MDPI Plants 8(2):34. DOI: 10.3390/plants8020034.

Rockström J, Falkenmark M, Karlberg L, Hoff H, Rost S, Gerten D (2009) Future water availability for global food production: The potential of green water for increasing resilience to global change. Water Resources Research 45:W00A12.

Rost S, Gerten D, Hoff H, Lucht W, Falkenmark M, Rockström J (2009) Global potential to increase crop production through water management in rain-fed agriculture. Environmental Research Letter 4:044002.

Schmitthenner AF (1985) Problems and Progress in Control of Phytophthora Root Rot of Soybean. Plant Disease 69:362-368.

Simtowe F (2011) Determinants of agricultural technology adaptation: the case of improved pigeon pea varieties in Tanzania. Alliance for Green Revolution in Africa (AGRA). MPRA Paper No. 41329, posted 04 October 2012 10:40 UTC. 23 pp. https://mpra.ub.uni-muenchen.de/41329/1/MPRA_paper_41329.pdf. Accessed on 24 January 2020.

Stelli S, Hoy L, Hendrick R, Taylor M (2018) Effects of different mulch types on soil moisture content in potted shrubs. Water S.A. 44:495-503.

The Chronicle (2011) Streambank cultivation affects water sources, quality. Zimpapers., Zimbabwe Newspaper. George Silundika and 9th Avenue Bulawayo. Wednesday, November 23, 2011 Edition. https://www.chronicle.co.zw/stream-bank-cultivation-affects-water-sources-quality/. Accessed on 21 February 2020.

Torriani D, Calanca P, Lips M, Ammann H, Beniston M, Fuhrer J (2007) Regional assessment of climate change impacts on maize productivity and associated production risk in Switzerland. Regional Environmental Change 16:23-29.

VARK Model (2020). https://blog.prezi.com/the-four-different-types-of-learners-and-what-they-mean-to-yourpresentations-infographic/ Accessed 04 January 2020).

Vítámvás P, Urban MO, Škodáček Z, Kosová K, Pitelková I, Vítámvás J, Renaut J, Prášil IT (2015) Quantitative analysis of proteome extracted from barley crowns grown under different drought conditions. Frontiers in Plant Science 6(Article 479):19 pp. DOI: 10.3389/fpls.2015.00479. 
VSG (Victoria State Government) (2018) About irrigation. Agriculture Victoria. The State of Victoria. http://agriculture.vic.gov.au/agriculture/farm-management/soil-and-water/irrigation/ about-irrigation. Accessed on 19 February 2020.

Wrigley C (2006) Global warming and wheat quality. Cereal Foods World 51(1):34-36.

Yadahalli GS, Vidyavathi GY, Srinivasareddy GV (2011) Mulching, one of the means to mitigate drought. Agrobios Newsletter 9(10):36-37.

You L, Ringler C, Wood-Sichra U, Robertson R, Wood S, Zhu T, Nelson G, Guo Z, Sun Y (2011) What is the irrigation potential for Africa? A Combined Biophysical and Socioeconomic Approach. Food Policy 36:770-782.

Zegada-Lizarazu W, Berliner PR (2011) The effects of the degree of soil cover with an impervious sheet on the establishment of tree seedlings in an arid environment. New Forests 42:2-17.

Zidana A, Kaunda E, Phiri A, Khalil-Edriss A, Matiya G, Jamu D (2007) Factors influencing cultivation of the Lilongwe and Linthipe River Banks in Malawi: A case study of Salima District. Journal of Applied Sciences $7(21): 3334-3337$. 